\title{
Strategy for the Sustainable use of Ecotourism in the Route of the Colombian Piedemonte
}

\author{
Sandra Acosta Guacaneme1, Freddy Díaz Díaz ${ }^{1}$
}

\begin{abstract}
The Colombian territory is characterized by a wide range of places with huge natural resources and vast tourist potential. However, most of this wealth and that potential are not properly used and in many cases are not even known or accessible. Armed conflict, geographical condition and the deficit of infrastructure are some of the reasons why many of those places remain forgotten and wasted, as sterile and unproductive elements of nature.

Our research is based on these questions and is heading towards the approach of a strategy of support for ecotourism that will allow the sustainable use of natural resources and the appropriation of land by communities. The case study is the route of the "Piedemonte Llanero" between two of the most important rivers in Colombia: The Casanare river and the Guaviare River.

The initial phase of the approach of the strategy is to identify, describe and characterize some nodes of interest along the route with an emphasis on 4 factors: economic, environmental and social, as mainstay of sustainability and the infrastructure as necessary support system for the sustainable development of the ecotourism activity.
\end{abstract}

Keywords: ecotourism, strategy, piedemonte, sustainable

\section{Introduction}

The vast natural areas of the Colombian territory are characterized not only by its biodiversity and richness but also by their tourism potential. Colombia is the country with the second-highest biodiversity in the world (COLCIENCIAS, 2016). Its tourism potential is due to its extraordinary landscapes, its diverse climates and cultural traditions. However, most of this natural wealth and potential are used inadequately, mainly unknown and hardly accessible. Most of these places remain abandoned and untapped due to their geographical condition, the complexity of the ecosystems, the deficit of infrastructure and the social problems, being considered as sterile and unproductive elements of nature.

Colombia has 46 National Natural Parks (NNP), among them the NNP Serranía de La Macarena, in the department of Meta, and the NNP El Cocuy, in the departments of Arauca and Boyacá. These two parks are the references, start and end, of the route that we have defined as case study. This route integrates the departments of Arauca, Casanare, Meta and Guaviare. The route begins Casanare River, which has headwaters in the NNP El Cocuy, flows defining the natural border between Arauca and Casanare and empties in the Guayabero River in the NNP Serranía de La Macarena.

The country is experiencing a remarkable situation after the signing of the peace treaty in 2016. This historical agreement offers an opportunity to explore the greatness of our 
vast and rich natural regions. However, this opportunity depends on overcoming violence, centralism and marginality. The local communities, historically marginalized, seeing the growing interest in eco-tourism as a possibility to improve their quality of life through the development sustainable economic activities based on the responsible use of natural resources. In this time called post-conflict, we have to open up the doors to the exploration of isolated and forgotten areas. This will deepen the understanding of our territory, our wealth and our potential. For this reason, our case study is a space clearly defined by visual elements, such as mountains and rivers, to the east of the eastern mountain range, where the piedmont foothills, traversed by the road "via marginal de la selva", joins with the Amazonian plain in wild, marginal and barely explored spaces.

We are bound together by the topic of ecotourism. For this reason, the article starts by defining its meaning. After that, the article characterized the site at different scales making a systematic reading of the specific conditions of the study area. Later, the article presents the findings and results of a site along the route that help to define an intervention strategy. And finally, the present the conclusions.

\section{Definition of Terms}

In order to contextualize our study, it is necessarily to make an explanation of the different tourism typologies. In this way, the ecotourism approach can be done, with its classification, localization, and how has been understood over time. It is important to highlight that the ecotourism as a typology of the tourism is relatively new, at which point its definition and classification in our days is very variable

\subsection{Sustainable tourism:}

The term sustainable is associated with a relationship in between the harmony and balance, guaranteed on the existence and permanence in time of what is referred, mainly to environmental, social or economic aspects. Hence, when we refer to sustainable tourism we refer to a condition that any type of tourism meets by guarantying an equitable relationship between the tourist and the environment. Within, economic earnings, low environmental impacts and a social recognition of the communities from the visited places happen; consequently, this activity can be indefinitely done without exhausting the necessarily resources. Accordingly, to the above, the sustainable tourism does not refer only to the tourism carried out in the natural places, but it consists on any activity developed in rural or urban environments, on different scales and in any type of social context in which the practices are conditioned to the sustainable principles.

\subsection{Nature tourism:}

This term is mainly used in Latin America, especially in Mexico, Guatemala and Colombia, where the richness in the ecological capital level is important. Is defined as an ample category that clusters all the tourism typologies that are carried out in contact with nature without defining sustainable, preservation or conservation conditions. In other words, it can be developed in a massive way, leading to questioning about the impact of exceeding the carrying capacity on the ecosystem. 


\subsection{Alternative Tourism:}

According to Ibáñez and Rodríguez (2012) it is characterized by allowing contact with nature, cultural expressions, communities interactions and heritage respect. The principle typologies within this modality are: Ecotourism, adventure tourism, rural tourism, agro tourism, cultural tourism and hunting tourism, each one with its own particularities.

\subsection{Ecotourism:}

The definition of ecotourism proposed by different authors were addressed from the typological point of view from conceptual approximations which are: Holing (2003), who defines it as "The ecologically sensitive trip, which combines the pleasures of discovering and understanding the spectacular flora and fauna by contributing in the same way to its conservation"; definition given by the experiential, conditioning it to the conservation. In addition, the Tourism Department in Chiapas in México (2003) defines it from the activity and the local benefit point of view, by clarifying that "It promotes the conscious relationship between man and nature without modifying the state of the environment visited, generating economic and cultural benefits for the population". Fennell and Williams (2015) presented a more contemporary vision where they included the learning concept and the non-consumerism: "Natural resources based tourism that focused primarily on experiencing and learning about nature and which is ethically managed to be low impact, non-consumptive and locally oriented"

The analysis of these definitions and the experience acquired in the fieldwork of the research behind this article, allows us to develop our own definition of ecotourism for the purposes of the strategy we intend to propose associated with the local context of the study area: Ecotourism is the typology of tourism based on the experience lived with nature guaranteeing its preservation, developed through its recognition, valuation and appropriation. Through this experience the environmental, social and economic dimensions are intertwined to ensure sustainability by recognizing the identity, culture and history of the local community and promoting their benefit.

\section{Between the "Piedemonte Llanero" and the Amazon Plain.}

We will begin by understanding the territory we are dealing with, based on three fundamental factors that may allow us to approach the problem: the geopolitical context, the ecologic structure and the economy and marginality of the territory.

\subsection{Geopolitical context of the study area:}

Since 1991, Colombia has been politically divided in 32 departments with the District Capital. Before this division, some of these territories considered today as departments were denominated Intendancies or Commissaries. This meant significant differences in the administrative independence of each territory, as the latter depended directly from the central government through the Administrative department of Intendancies and Commissaries. The area object of this study is located in 4 departments 
of the national territory of which 2, Arauca and Casanare were considered Intendancies and 1 the Guaviare was considered Commissary.

Our area of study begins in the Casanare River whose source is in the Cocuy NNP whose course is the borderline between the departments of Arauca and Casanare, in the Sub-region of the Piedemonte Llanero and ends in the Guayabero River in the Serranía de La Macarena NNP. The territories that belongs to the plains sub-regions of the Meta and Guaviare Rivers and the Amazon plain, are included in this area.

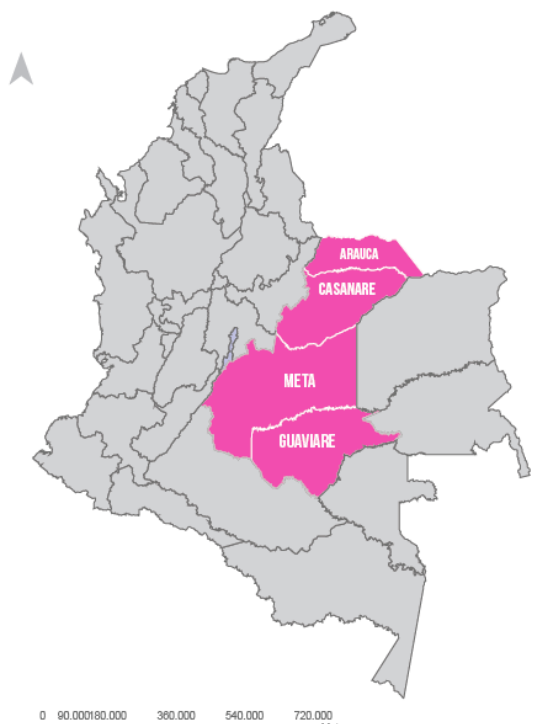

Figure 1 - Political Map of Colombia, departments involved.

Source: Own elaboration Research Group - based on the IGAC cartography

\subsection{Ecologic structure:}

In a bio-diverse country of enormous ecological complexity where more than the $50 \%$ of the territory still has natural ecosystems, the ecologic structure must be seen as a fundamental element and base of the environmental resources that we have as Colombians. It is defined as: "All natural and semi-natural ecosystems that have a localization, extension connections and state of health that ensures the maintenance of the integrity of biodiversity and the provision of environmental services as a measure to guarantee the satisfaction of the basic needs of the inhabitants and the perpetuation of life." (IDEAM, Ministerio de ambiente vivienda y Desarrollo, 2005) Water, especially in this territory is a key element of the ecologic structure because of the extensive hydrographic system that characterizes the area of study with countless rivers, lagoons and canals. Its connectivity with the rest of the elements of the structure like the forests and plains, offer and guarantee the biodiversity. 


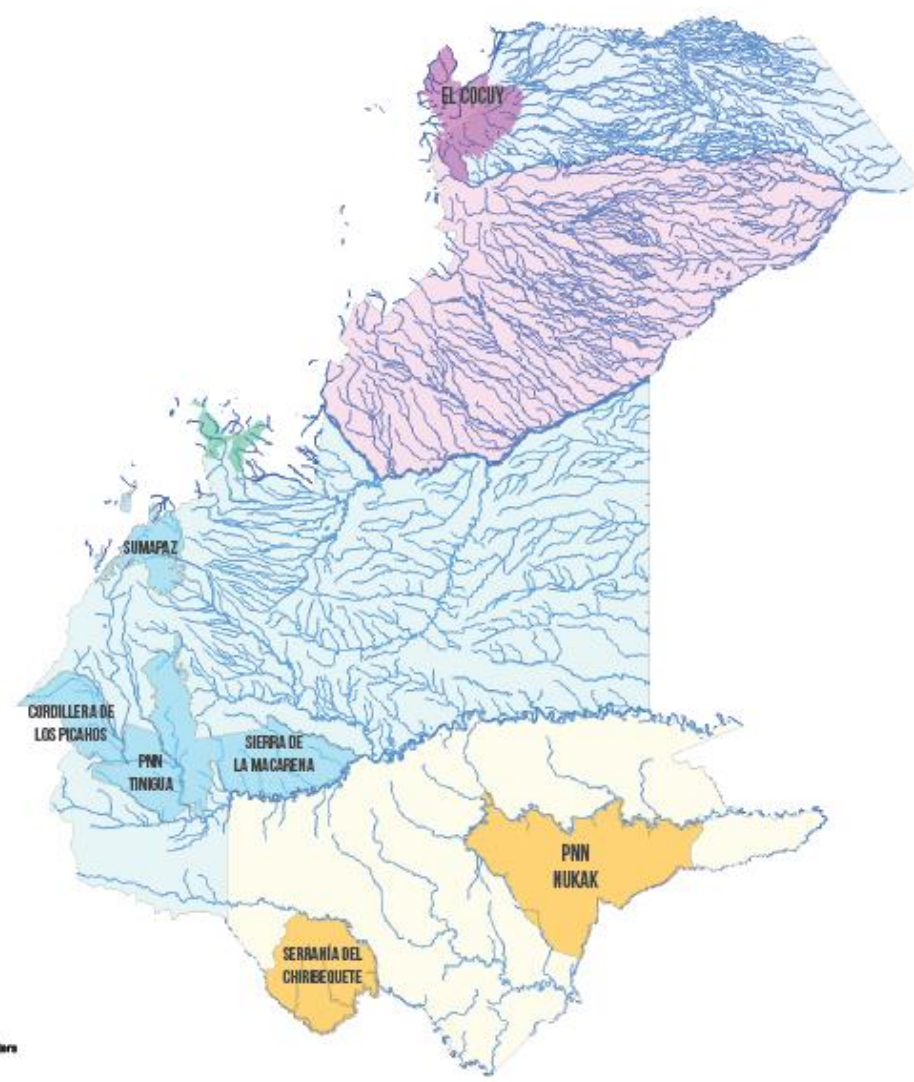

Figure 2 - Hydrographic structure in the area of study.

Source: Own elaboration Research Group - based on the IGAC cartography

\subsection{Economy and marginality of the territory:}

Since the epoch of the Spaniard colonization these territories were seen with a lack of interest as they were not within the extractive network that privileged the territories located in the Magdalena River and therefore those that were connected with the ports of the Caribbean Sea. Historically, various phenomena have favored the marginality of the region maintaining it excluded and isolated from the rest of the country: The low agricultural productivity, as a result mainly of the acidity of the soil and the extreme and prolonged climatic conditions. The concentration of land in large estates, mainly of cattle breeders through which fewer people own more and more land. Lastly, the armed conflict that has been probably the most determining factor, as this region saw the birth of the first guerrillas in the decade of the 50s, the paramilitary groups in the $80 \mathrm{~s}$ and it also has been the scenario of hundreds of kidnappings, massacres and attacks to the population along 60 years of violence. This has generated economic and tourism disinterest from the rest of the country.

The marginality condition described above and the phenomena that configures it have allowed the development of three economical activities in the last 60 years: 1) Petroleum extraction that begins in the decade of the 60 s and along 20 years the region has managed to overcome the precariousness of infrastructure and minimal public services 
leaving negative social and environmental impacts. On the one hand, migration of people in the region in search of job opportunities appeared, causing inflationary effects, increasing the insecurity, the armed conflict and the prostitution. (Aguilar, Galeano, Pérez y CORPES, 1998) On the other, an imbalance over the landscape was produced, as well as a latent risk of pollution in the water bodies. 2) The extensive livestock farming rooted in the cultural traditions of the inhabitants of the plain, developed since Independence, has negative environmental impacts. (Ausdal, 2008) This activity requires vast areas of pastures where the shrub and tree vegetation has to be replaced by cover crops. Likewise, the agricultural frontier need to be displaced and the wetlands and water sources "repaired" 1 as they cause considerably and irreversible environmental impacts. "We should understand that is more valuable a hectare of forest than a hectare of pastures, as an economic and ecologic resource" (Reyes, 2016).3) The illicit crops as a consequence of the growing presence of the drug traffickers in the region since the 80s. By $1998,54,7 \%$ of the agricultural jobs of the Guaviare, were related to crops of coca. (Galvis, 2002) Moreover, in the Distention Zone formed by 5 municipalities, the guerrilla not only strengthened militarily, but also expanded the illicit crops areas and positioned an economy based on the drug.

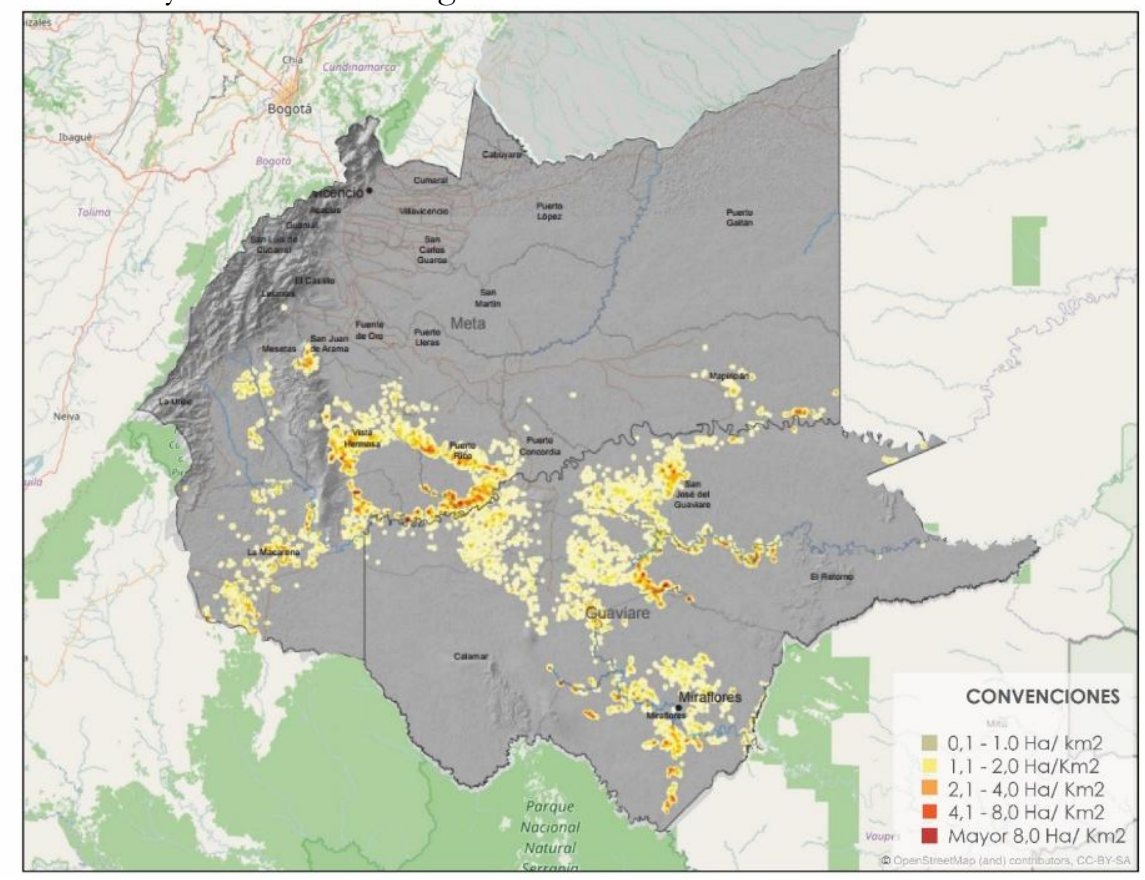

Figure 3 - Density of coca plantations. Source: Own elaboration Research Group based in the Government of Colombia - Monitoring system supported by UNODC

In spite of this socio-economic context, the signing of the Peace Agreement in 2016 and the beginning of a period named post-conflict, ecotourism appears as an alternative to energize the region and as an opportunity to propel sustainable development in all the national territory that have suffered for decades the impacts of violence. The recent

${ }^{1}$ By repairing it, the inhabitants of the region refer to the draining and the drying for sowing grasses. 
initiatives directed to a different type of tourism have been welcome by locals and foreigners in places where enormous natural resources are hidden and where the communities consider ecotourism as a visible and sustainable economic activity that could bring these marginal territories to integrate effectively in the productivity of the country.

\section{Puerto San Salvador: Node and Start of a Route}

Once the fundamental concepts are defined and the area of study is contextualized, we identified the sections that make up the route to later perform a detailed characterization of each node in 4 aspects: Economy, Sociocultural, and Environmental, as pillars of the sustainability and the infrastructure that supports the ecotourism activity. In this regard, we can approach methodologically the proposal in a subsequent stage to this research from the strategy of ecotourism benefit.

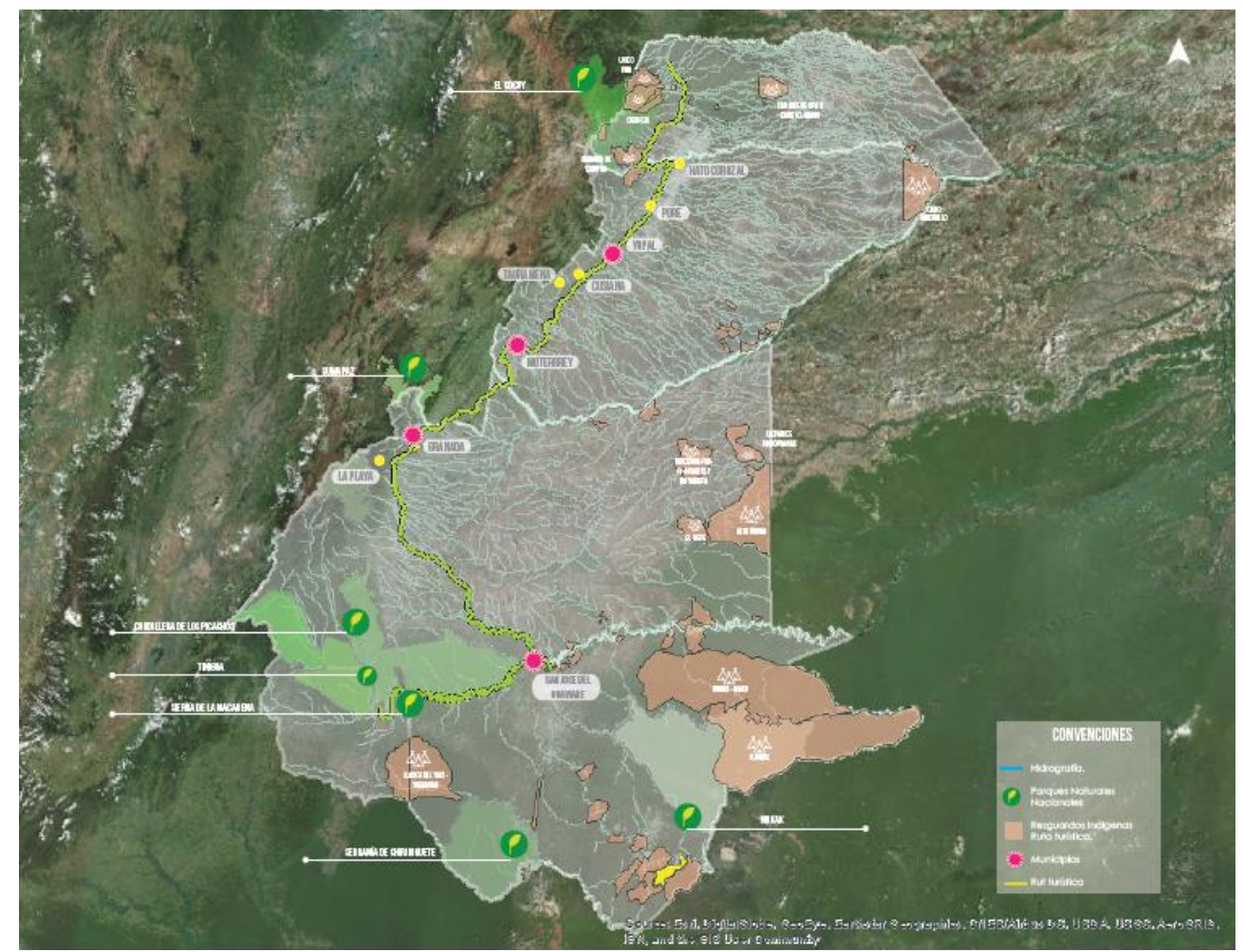

Figure 4 - Ecotouristic route proposed.

Source: Own elaboration Research Group - based on the IGAC cartography

In the area of study, we have identified 3 sections: 1) First section, which starts in Puerto San Salvador, in the municipality of Tame, Arauca and ends in Villavicencio, capital of the department of Meta. This section dominated by the Plain Foothill is characterized by the multiplication of hydrological basins coming from the eastern mountain range. This hydric resource is essential in the area, where it shows its wealth and importance by the 
number of rivers, canals and streams that cross the route of this road. 2) Second section: It starts in Villavicencio and ends in San José del Guaviare. This route limits the plains and the jungle, is the part where the 2 ecosystems mediate and a transition between the Orinoquía and the Amazon. 3) Third section: Starts in San José del Guaviare, the door to the jungle, and ends in the municipality of La Macarena, Meta in a fluvial route along the Guayabero River in the territories of the NNP of the Serranía de La Macarena.

In the present article, we present some of the findings of the node that marks the beginning of the route: Puerto San Salvador, mainly as an infrastructure that supports the Eco-touristic activity based on 3 components of the Boullon (2006) approach: the touristic infrastructure, equipment and facilities.

\subsection{Touristic infrastructure:}

Two categories were analyzed in this component: Access roads and public services. Related to the access roads, we found that San Salvador has a privileged location as it is located on the marginal road of the jungle, which is a main way linking the departments of Casanare and Arauca. From a bigger scale, this main road is part of a road-project that aims to communicate Venezuela, Colombia and Ecuador. This pathway is paved and in good condition, has a single line with one lane in each direction, wellmarked and signposted. Additionally, the bridge located precisely in San Salvador is in optimal conditions. By this route it is possible to be accessed by the south from Yopal, located at $153 \mathrm{~km}$ and Hato Corozal at $20 \mathrm{Km}$ and from the north from the urban area of Tame located at $34 \mathrm{Km}$. Once inside the hamlet, the roads are uncovered without any maintenance and defined by the way people have taken over the territory informally for several years.

Table 1 - Matrix of inventory of infrastructure in San Salvador. Source: Own Elaboration

\begin{tabular}{|c|c|c|c|c|c|c|c|c|c|c|}
\hline \multicolumn{11}{|c|}{ MATRIX OF INVENTORY OF TOURIST INFRASTRUCTURE } \\
\hline \multicolumn{2}{|c|}{ PLACE } & \multirow[t]{3}{*}{ Puerto San Salvador } & \multicolumn{2}{|c|}{ DATE: } & \multicolumn{2}{|c|}{$1 / 01 / 2018$} & & & & \multirow{3}{*}{\begin{tabular}{|c}
$\%$ COVERAGE \\
RURAL
\end{tabular}} \\
\hline & & & EXIST. & \multicolumn{3}{|c|}{ CONDITION } & \multicolumn{3}{|c|}{ DISTANCE } & \\
\hline & & & \begin{tabular}{|l|l|}
$\mathrm{Y}$ & $\mathrm{N}$ \\
\end{tabular} & GOOD & REGULAR & BAD & KM & REF & TIME & \\
\hline \multirow{13}{*}{ 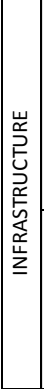 } & \multirow{7}{*}{ 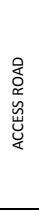 } & \multirow{3}{*}{ TERRESTRIAL } & & & & & $20 \mathrm{KM}$ & HATO COROZAL & $20 \mathrm{MIN}$ & \\
\hline & & & & & & & $34 \mathrm{KM}$ & TAME & $32 \mathrm{MIN}$ & \\
\hline & & & & & & & $153 \mathrm{~km}$ & YOPAL & $2 \mathrm{H} 20 \mathrm{MIN}$ & \\
\hline & & FLUVIAL & & & & & & & & \\
\hline & & \multirow{3}{*}{ AERIAL } & & & & & $35,6 \mathrm{KM}$ & TAME & $35 \mathrm{MIN}$ & \\
\hline & & & & & & & $157 \mathrm{KM}$ & YOPAL & $2 \mathrm{H} 31 \mathrm{MIN}$ & \\
\hline & & & & & & & $105 \mathrm{KM}$ & SARAVENA & $1 \mathrm{H} 42 \mathrm{MIN}$ & \\
\hline & \multirow{6}{*}{ 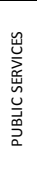 } & ELECTRICITY & & & & & & & & $37,14 \%$ \\
\hline & & DRINKABLE WATER SUPPLY & & & & & & & & $30,00 \%$ \\
\hline & & SEWERAGE & & & & & & & & $0,80 \%$ \\
\hline & & INTERNET & & & & & & & & $0,00 \%$ \\
\hline & & PHONE AND DATA & & & & & & & & $0,62 \%$ \\
\hline & & TV & & & & & & & & \\
\hline
\end{tabular}

Related to the airway, the nearest airports to San Salvador are: the Tame airport, where the commercial flights from the Satena airline arrive from Bogotá once per week. The Saravena airport where the commercial flights from the Satena airline arrive from Bogotá and Bucaramanga three times per week; and at last the Yopal airport where the commercial flights arrive from the airlines like Avianca, LATAM, Easyfly and Satena with a frequency of 10 flights per day from Bogotá and Bucaramanga. San Salvador is located over the Casanare River, hence it exist fluvial communication with some hamlets 
and municipalities located on the river. Although there is no organized commercial or any passenger's navigation in the area, many of its inhabitants have motorized canoes that offer this service informally on demand.

The second category analyzed corresponds to the public services. Here can be identified that the coverage in this rural area is precarious. The only public service that has a high coverage in the houses is the electricity; nonetheless frequent blackouts occur. The municipality installed public lightning several years ago, with concrete posts and luminaries that were damaged and never repaired; today none of them functions. Referring to the DANE (2005) the rural coverage of electricity in the municipality of Tame was 37,14\%.

Concerning the aqueduct, in the village some reserve tanks were built with a purification chemical with the intention of being the reserve for the supply of the municipality aqueduct that should cover the local population; though the population prefer to consume the water of the river. The sewerage system does not exist and all the houses must have septic tanks built by them. This generates serious sanitarian problems and a latent risk to nearby water bodies. The rural area of the municipality has aqueduct coverage of just $30 \%$ and $0,8 \%$ of sewerage system (DANE, 2005). Other services such as telephony, Internet or television do not have any presence of public or private entities.

\subsection{Touristic equipment:}

Referring to the component of tourism equipment we identified 4 categories. In the first instance, it was identified that the little village does not has any health station, consequently for any medical event it is necessary to travel $20 \mathrm{Km}$ to Hato Corozal where a health center can be found. In other circumstances, the people have to approach to the urban area of Tame where there is a hospital and a clinic. Nonetheless for specialized attention or the 3rd level care, the person has to travel until Yopal.

Table 2 - Matrix of inventory of equipment in San Salvador. Source: Own Elaboration

\begin{tabular}{|c|c|c|c|c|c|c|c|c|c|}
\hline \multicolumn{10}{|c|}{ MATRIX OF INVENTORY OF TOURIST INFRASTRUCTURE } \\
\hline \multicolumn{2}{|c|}{ PLACE } & \multirow[t]{3}{*}{ Puerto San Salvador } & \multicolumn{4}{|c|}{$1 / 01 / 2018$} & & & \\
\hline & & & EXIST. & & CONDITION & & \multicolumn{3}{|c|}{ DISTANCE } \\
\hline & & & \begin{tabular}{|l|l|}
$Y$ & $N$ \\
\end{tabular} & GOOD & REGULAR & BAD & KM & REF & TIME \\
\hline \multirow{14}{*}{ 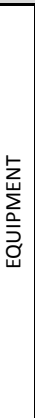 } & \multirow{3}{*}{$\begin{array}{l}\text { I⿱ } \\
\text { 离 } \\
\text { 离 }\end{array}$} & LOCAL HEALTH CENTER & & & & & $20 \mathrm{KM}$ & HATO COROZAL & $20 \mathrm{MIN}$ \\
\hline & & CLINIC & & & & & $34 \mathrm{KM}$ & TAME & $32 \mathrm{MIN}$ \\
\hline & & HOSPITAL & & & & & $153 \mathrm{KM}$ & YOPAL & $3 \mathrm{H}$ \\
\hline & \multirow{2}{*}{ ठં } & CONVENIENCIA & & & & & & & \\
\hline & & ESPECIALIZADO & & & & & $20 \mathrm{KM}$ & HATO COROZAL & $20 \mathrm{MIN}$ \\
\hline & \multirow{6}{*}{$\begin{array}{l}z \\
\text { z } \\
\text { E } \\
\text { Oे } \\
\text { ¿ } \\
\text { ष }\end{array}$} & CAMPING & & & & & & & \\
\hline & & HAMACS & & & & & & & \\
\hline & & ROOMS & & & & & $20 \mathrm{KM}$ & HATO COROZAL & $20 \mathrm{MIN}$ \\
\hline & & CABINS & & & & & & & \\
\hline & & HOSTAL & & & & & & & \\
\hline & & HOTEL & & & & & $35,6 \mathrm{KM}$ & TAME & $35 \mathrm{MIN}$ \\
\hline & \multirow{3}{*}{ 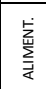 } & RESTAURANT & & & & & $400 \mathrm{M}$ & CARRETERA & $7 \mathrm{MIN}$ \\
\hline & & \begin{tabular}{|l|} 
FAST FOOD \\
\end{tabular} & & & & & & & \\
\hline & & BAKERY & & & & & & & \\
\hline
\end{tabular}


The second category is the commerce where we identify a very precarious convenience trade in the area, based on a mini-market, a butcher shop and a couple of shops. For any other type of commerce, the person has to go to Hato Corozal or Tame.

The third category consists on the accommodation equipment. It is evident that this location has an enormous potential, as the houses are susceptible of being transformed for the accommodation service purpose; unfortunately, at the moment there is no accommodation equipment that offers this type of service at any level. Some inhabitants have in their houses arbors where they can hang hammocks to receive visitors or seasonal fisherman. Likewise, there are many free areas nearby the houses where some camping can be installed; as well it exists bigger houses that can provide dormitories. It is important to have in mind, that the ecotourism as an alternative tourism typology is not based on luxuries or extreme comforts, but it does require spaces to spend the night with the necessarily basics.

The fourth category includes the food equipment, where again the offer is minimal. There is only one restaurant along the road where its owner prepares and sells the 3 meals of the day with the proper hospitality of the inhabitants of the region, although it has the precarious sanitary conditions found in the little village.

\subsection{Facilities:}

The facilities were analyzed on the basis of the ecotourism attractions identified. In first place, the hamlet counts with improvised docks made by the inhabitants to fish and also to be used as tourist docks. In addition, the entire river round can be considered a natural viewpoint on which to create suitable spaces for this purpose that do not exist today. There are also no bathrooms or shelters, neither bathing establishments because of the river stream. 
Table 3 - Matrix of inventory of facilities in San Salvador. Source: Own Elaboration

\begin{tabular}{|c|c|c|c|c|c|c|c|}
\hline \multicolumn{8}{|c|}{ MATRIX OF INVENTORY OF TOURIST INFRASTRUCTURE } \\
\hline \multicolumn{2}{|c|}{ PLACE } & \multicolumn{3}{|l|}{ Puerto San Salvador } & \multirow[t]{2}{*}{ DATE: } & \multicolumn{2}{|c|}{$1 / 01 / 2018$} \\
\hline & & & \multicolumn{2}{|c|}{ EXIST. } & & \multicolumn{2}{|c|}{ CONDITION } \\
\hline & & & $\mathrm{Y}$ & $\mathrm{N}$ & GOOD & REGULAR & BAD \\
\hline \multirow{8}{*}{ 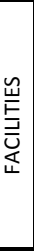 } & \multirow{8}{*}{$\begin{array}{l}\frac{0}{x} \\
\frac{\breve{y}}{u}\end{array}$} & DOCKS & & & & & \\
\hline & & VIEWPOINT & & & & & \\
\hline & & SANITARY FACILITIES & & & & & \\
\hline & & PATHS & & & & & \\
\hline & & REFUGES & & & & & \\
\hline & & INTERNAL TRANSPORT & & & & & \\
\hline & & BATHS & & & & & \\
\hline & & BRIDGES & & & & & \\
\hline \multirow{8}{*}{ 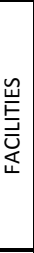 } & \multirow{8}{*}{ 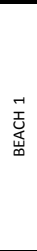 } & DOCKS & & & & & \\
\hline & & VIEWPOINT & & & & & \\
\hline & & SANITARY FACILITIES & & & & & \\
\hline & & PATHS & & & & & \\
\hline & & REFUGES & & & & & \\
\hline & & INTERNAL TRANSPORT & & & & & \\
\hline & & BATHS & & & & & \\
\hline & & BRIDGES & & & & & \\
\hline \multirow{8}{*}{ 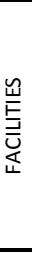 } & \multirow{8}{*}{ 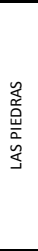 } & DOCKS & & & & & \\
\hline & & VIEWPOINT & & & & & \\
\hline & & SANITARY FACILITIES & & & & & \\
\hline & & PATHS & & & & & \\
\hline & & REFUGES & & & & & \\
\hline & & INTERNAL TRANSPORT & & & & & \\
\hline & & BATHS & & & & & \\
\hline & & BRIDGES & & & & & \\
\hline \multirow{8}{*}{ 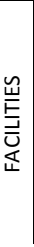 } & \multirow{8}{*}{ 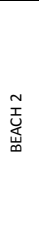 } & DOCKS & & & & & \\
\hline & & VIEWPOINT & & & & & \\
\hline & & SANITARY FACILITIES & & & & & \\
\hline & & PATHS & & & & & \\
\hline & & REFUGES & & & & & \\
\hline & & INTERNAL TRANSPORT & & & & & \\
\hline & & BATHS & & & & & \\
\hline & & BRIDGES & & & & & \\
\hline
\end{tabular}

Other attractions considered for the analysis have been named beach 1 and beach 2 . It is about two places on the riverside of the Casanare River to the west of the small villa, where the conditions are proper for a bathing establishment as the waters are less torrential, the sand is soft and the beaches are wide. These places do not have any human intervention or construction justifying these aspects as part of the charm and ecotouristic potential. Another similar place is the one we name beach rocks that instead of sand has gravel. This characteristic makes it less comfortable for the bathing, but very attractive for its contemplation.

\section{Conclusion}

This diagnostic journey, between two of the most important NNP of Colombia, constituted a base panorama to propose an intervention strategy. This strategy can structure a support system for ecotourism in a region that is gaining growing attention and visibility for urban inhabitants, researchers and institutions. 
The conditions that have been identified in this research allowed to increase awareness about the enormous Colombian's natural wealth found in regions that are often remote and forgotten due to socio-economic and political conflicts. We see in ecotourism an outstanding possibility to promote social and economic cohesion and a unique opportunity to add value to vast extensions of rich land. This richness is based on a twofold perspective. First, water as the most valuable resource. Second, the sustainable and alternative appropriation of the place by local communities that can coproduce an alternative to the decades of irresponsible exploitation of resources, war and marginality.

\section{References}

Aguilar, O., Galeano, C. \& Pérez, L. (1998). Petróleo y Desarrollo. In D. Fajardo, \& F. Urbina, (Eds), Colombia Orinoco. Bogotá: FEN Colombia.

Ausdal, S. (2008). Un mosaico cambiante: Notas sobre una geografía histórica de la ganadería en Colombia. Bogotá: Pontificia Universidad Javeriana.

Galvis, J. (2002). La dimensión urbana de la marginalidad en la Orinoquía. Tres dinámicas diferentes de su reproducción. Revista Territorios, 7, 89-107.

Holing, W. (2003). La guia del ecoturismo. Madrid: Mundi-prensa

Ibáñez, Reyna y Rodriguez, Ismael (2012) Tipologías y antecedentes de la actividad turística: turismo tradicional y turismo alternativo. En Ivanova, Antonina e Ibáñez, Reina (Eds.)(2012) Medio ambiente y política turística en México Tomo I: Ecología, biodiversidad y desarrollo turístico (17-33). México D.F.: SEMARNAT

IDEAM, Ministerio de ambiente vivienda y Desarrollo. (2011). Estructura ecológica principal de Colombia. Bogotá. Ministerio de comercio, industria y turismo. (2003). Politica para el desarrollo del ecoturismo. Bogotá.

Ministerio de comercio, industria y turismo. (2012). Guía turística Meta. Bogotá: Fondo de Promoción turística Colombia.

Ministerio de comercio, industria y turismo. (2012). Guía turística Casanare. Bogotá: Fondo de Promoción turística Colombia.

Reyes, A. (2016). La violencia y el problema agrario en Colombia. Bogotá.

Williams, S. (2015). Tourism Geography. New York: Routledge. 